\title{
PUPUR DINGIN SEBAGAI PERAWATAN WAJAH KHAS MASYARAKAT BANJAR
}

\author{
Haris Fadillah \\ Program Studi Pendidikan Sejarah \\ Fakultas Keguruan dan IImu Pendidikan \\ Universitas Lambung Mangkurat Banjarmasin
}

\begin{abstract}
"Pupur dingin" or bedak dingin is a traditional facial treatment based on the local wisdom of South Kalimantan which has been used by Kalimantan women for a long time. Apart from its function as skin care from sunburn, in addition to that pupur dingin is also much in demand as a typical souvenir from Banjar, South Kalimantan. Pupur dingin craftsmen in Pasayangan sub-district, Banjar district, are still able to produce products because they want to maintain the legacy of their previous people. Seeing the potential of pupur dingin that is not only interested by local people but also by people from outside the region has the potential to be developed. However, the production of pupur dingin during the rainy season cannot be done because the drying process is very dependent on sunlight. Pupur dingin is used to protect the skin while working in the fields in the hot sun.
\end{abstract}

Keywords: pupur dingin, skin care, local wisdom

\begin{abstract}
ABSTRAK
"Pupur dingin" atau bedak dingin merupakan perawatan wajah tradisional yang berbasis kearifan lokal Kalimantan Selatan yang telah digunakan oleh wanita Kalimantan sejak dahulu. Selain fungsinya sebagai perawatan kulit (skin care) dari sengatan matahari, selain itu pupur dingin juga banyak diminati sebagai oleh-oleh khas Banjar Kalimantan Selatan. Pengrajin bedak dingin di kelurahan Pasayangan Kabupaten Banjar, masih bertahan untuk dapat memproduksi juga disebabkan karena ingin mempertahankan tradisi warisan dari orang terdahulu. Melihat potensi dari bedak dingin yang tidak hanya diminati masyarakat lokal tetapi juga diminati oleh masyarakat dari luar daerah berpotensi untuk dapat dikembangkan. Namun produksi bedak dingin apabila musim hujan tidak bisa dilakukan karena proses pengering sangat tergantung dengan sinar matahari. Pupur dingin digunakan untuk melindungi kulit selama bekerja di ladang di bawah terik matahari.
\end{abstract}

Kata Kunci: pupur dingin, perawatan wajah, kearifan lokal

\section{PENDAHULUAN}

Indonesia merupakan negara beriklim tropis, karena letaknya dilewati oleh garis khatulistiwa menyebabkan Indonesia mendapatkan intensitas matahari yang tinggi. Sinar ultraviolet dan cuaca panas menyebabkan kondisi kulit menjadi kering dan kusam, oleh karena itu kulit membutuhkan perawatan baik dari dalam maupun luar. Perawatan kulit dari dalam adalah dengan mengkonsumsi makanan yang berguna bagi kesehatan kulit wajah, misalnya mengkonsumsi makanan yang banyak mengandung vitamin $\mathrm{C}, \mathrm{D}$, dan E. Perawatan kulit wajah dari luar dapat dilakukan dengan menggunakan kosmetik yang dioleskan pada 
permukaan kulit wajah. Kosmetik sudah dikenal dan digunakan manusia sejak ribuan tahun yang lalu, bermanfaat untuk mempercantik wajah dan melindungi kulit dari pengaruh cuaca dan serangga. Kosmetika merupakan salah satu kebutuhan sekunder yang semakin terus meningkat karena adanya keinginan manusia yang selalu ingin semakin cantik khususnya wanita. Kosmetika merupakan bahan-bahan yang digunakan untuk memberikan dampak kecantikan dan kesehatan bagi tubuh. Menurut Dewi Muliyawan (2013: 11), kosmetik berasal dari kata kosmetikos (Yunani) yang artinya keterampilan menghias, mengatur. Jadi kosmetik pada dasarnya adalah campuran bahan yang diaplikasikan pada anggota tubuh bagian luar seperti epidermis kulit, kuku, rambut dan sebagainya dengan tujuan untuk menambah daya tarik, melindungi, memperbaiki, sehingga penampilannya lebih cantik dari semula. Banyak perempuan berupaya agar ia tampil cantik. Untuk mendapatkan tubuh yang sempurna, banyak perempuan melakukan perawatan kecantikan. Perawatan kecantikan tersebut bisa dilakukan sendiri di rumah dan tidak sedikit dilakukan perawatan kecantikan di luar rumah seperti di salon, spa, sauna, body treatment, body message, dan klinik kecantikan. Oleh sebab itu sekarang ini banyak bermunculan jasa-jasa kecantikan sebagai tempat mempercantik dan perawatan tubuh, baik yang bersifat modern maupun tradisional.

Adanya tren back to nature membuat industri kosmetik yang berbasis dari herbal berprospek cerah. Penggunaan produk yang dahulu hanya sebagai kebutuhan sekunder kini berkembang menjadi kebutuhan primer, terutama bagi perempuan. Tren masyarakat menggunakan bahan baku alami semakin meningkat. Ini membuka peluang dan kreativitas industri kosmetik di dalam negeri. Data Kemenperin menyebutkan, omzet industri kosmetik tahun 2010 sebesar Rp 8,9 triliun dan naik menjadi Rp 10,4 triliun tahun 2011. Hal itu menyebabkan industri kosmetika yang berbasis herbal berpotensi untuk dikembangkan (Fadlilatur dan Hidayat, 2019: 2).

Bedak dingin adalah campuran tepung pati dengan bahan pengharum, kadang-kadang ditambah dengan bahan pelembab, penahan sinar ultraviolet dan antiseptik yang berbentuk butiran kecilkecil kering, memiliki warna dan aroma sesuai dengan komposisinya. Bahan baku utama pada proses pembuatan bedak dingin adalah tepung beras. Tahap-tahap pembuatan bedak dingin adalah pencampuran bahan, penggelintiran, dan pengeringan. Menurut Sari, proses pebuatan bedak dimulai dengan menggiling bahan yang akan dicampurkan dengan derajat kehalusan tertentu (Sari dalam Banjar, K. P. K, 2019). Penelitian Yulianti \& Binarjo (2010) ukuran partikel bedak dingin sangat mempengaruhi mutu dari bedak dingin yang dihasilkan (Yulianti dan Binarjo dalam Banjar, K. P. K, 2019) Setelah diaduk rata, secara perlahan-lahan ditambahkan akuades sehingga berbentuk pasta. Adonan ini kemudian digelintir membentuk bulatan-bulatan kecil dan dikeringkan dengan cara menjemurnya (Susianti dalam Banjar, K. P. K, 2019). Tanaman bangkal merupakan tanaman khas dari Kalimantan Selatan yang dimanfaatkan bagian kulit batangnya sebagai bahan dari pembuatan "pupur dingin". Ekstrak etanol kulit batang bangkal memiliki efektivitas sebagai tabir surya (Rahmawanty dalam Banjar, K. P. K, 2019) Penggunaan "pupur basah" secara turun temurun telah dipercaya sebagai perawatan kulit (skin care) dari sengatan matahari. Pasayangan adalah salah satu kelurahan yang terletak di Kecamatan Martapura, Kabupaten Banjar, Provinsi Kalimantan Selatan, Indonesia. Di kelurahan ini terdapat pengrajin pembuat "pupur basah" yang masih menjaga warisan leluruh budaya khas Banjar, Kalimantan Selatan. 


\section{PUPUR DINGIN}

Kearifan lokal di Banjarmasin yang terkait kecantikan ini disebut dengan tradisi bapupur. Bapupur adalah mengoleskan bedak yang dibasahi atau dicapur dengan air kemudian dioleskan di seluruh wajah dengan tujuan melindungi wajah dari terik matahari supaya tidak terasa panas dan tidak menjadikan kulit wajah hitam akibat paparan sinar matahari. Sampai saat ini kebiasaan bapupur ini masih sering kita temui di Banjarmasin pada perempuan-perempuan pedagang di pasar yang aktivitasnya menggunakan alat transportasi kelotok. Mereka melindungi wajah dengan bapupur dan menggunakan topi lebar yang terbuat dari rotan yang disebut dengan "tanggui." Aktivitas mereka di pasar tidak terganggu dan terlihat biasa saja dengan bapupur. Tetapi orang luar yang tak terbiasa melihat perempuan bapupur akan terlihat menggelikan dengan wajah putih penuh dengan bedak basah yang telah mengering. Bapupur ini juga digunakan oleh lelaki Banjar yang biasanya melakukan aktivitas "maujun" atau memancing. Tujuannya sama untuk melindungi wajah dari terik matahari agar tidak terasa panas dan menghitam (Nurdiyana dan Najamudin, 2019)

Pupur dingin merupakan bedak tradisional Banjar khas Kalimantan Selatan. Fungsinya untuk menghaluskan, mengencangkan dan memutihkan kulit. Bedak ini sejak ratusan tahun silam memang sudah dikenal dan akrab dengan kehidupan sehari-hari orang Banjar. Pemakainya bisa laki-laki juga perempuan dan untuk segala usia. Mereka biasa memakainya di waktu senggang. Waktu pemakaiannya bisa kapan saja, bisa pagi, siang atau malam. Caranya, cukup dicampur dengan air lalu dioleskan ke wajah dan badan. Pupur dingin biasanya dipakai oleh penjual atau acil (dalam bahasa banjar) ketika mereka bekerja diladang, diwarung atau dipasar terapung floating market (Anis, 2017).

Menurut Susianti (dalam Dianzy, 2015) fungsi bedak dingin adalah untuk melindungi kulit dari sengatan matahari, mencegah timbulnya biang keringat, mencegah timbulnya keriput pada kulit dan menciutkan pori-pori kulit yang melebar. Beers (dalam Dianzy, 2015) menjelaskan bahwa iklim tropis dapat membantu perawatan kecantikan kulit dengan proses keluarnya keringat pada kulit, proses alami tersebut menyebabkan pori-pori menjadi terbuka sehingga kotoran mudah masuk dan keluar. Bedak dingin digunakan untuk mencegah timbulnya keriput pada kulit dan menciutkan pori-pori kulit yang melebar. Iklim tropis juga menjadi sebab wanita Indonesia menggunakan bedak dingin untuk mencegah biang keringat.

Bahan dasar pembuatan bedak dingin adalah tepung beras, yaitu tepung beras yang diperoleh dari beras putih yang direndam dengan air selama 1 hari agar tekstur beras lebih lunak. Beras mengandung beberapa komponen yaitu karbohidrat, protein, lemak, vitamin E, gamma oryzanol dan lainnya. Beras mengandung vitamin B1 (Thiamin) mampu mempertahankan kelembaban dan kesegaran kulit di saat matahari siang sangat terik (Sumandari dalam Dianzy, 2015) Beras mengandung vitamin E yang bermanfaat untuk kesehatan kulit sehingga kulit nampak lebih muda, vitamin B bermanfaat menjadikan kulit segar dan bersih, zat oryzanol bermanfaat sebagai penangkal sinar ultraviolet yang bisa merusak kulit. Bedak dingin dengan bahan dasar tepung beras berfungsi untuk menghaluskan kulit (Susanti dalam Dianzy, 2015) 


\section{PERAWATAN WAJAH KHAS MASYARAKAT BANJAR}

Kecantikan tidak lepas dari etnisitas, karena suatu etnis atau masyarakat tertentu memaknai kecantikan akan berbeda dengan etnis atau masyarakat lainnya. Pada kajian ini akan membahas mengenai kecantikan dalam konteks etnisitas yaitu etnis atau masyarakat Banjar di Kota Banjarmasin Kalimantan Selatan. Kajian tentang makna perilaku kecantikan oleh perempuan Banjar menarik untuk dikaji karena perilaku mempercantik diri perempuan Banjar dilakukan oleh semua kelas ekonomi perempuan Banjar dari yang muda atau remaja sampai perempuan yang sudah tua, dari yang belum menikah sampai yang sudah menikah. Prilaku mempercantik diri oleh perempuan Banjar mereka wujudkan dalam melakukan perawatan kecantikan (Spa Banjar) seperti urut, lulur, timung, pupur dan ratus (dalam istilah Bahasa Banjar adalah baurut, balulur, batimung, bapupur dan baratus) dalam periode waktu tertentu secara rutin sesuai dengan kebutuhan sehingga perawatan kecantikan sudah mendarah daging bagi semua lapisan perempuan Banjar yang ada di Banjarmasin. Massifnya prilaku mempercantik diri perempuan Banjar terlihat dari begitu banyaknya fasilitas kecantikan di Kota Banjarmasin. Di Kota ini masih banyak ditemukan jasa perawatan kecantikan khas Banjar. Ada beberapa bentuk perawatan kecantikan yang ditemukan peneliti yang penggunaan jasanya disesuaikan dengan keperluan dan ketersediaan anggaran keuangan perempuan yang akan melakukan perawatan kecantikan. Perawatan kecantikan yang dilakukan oleh tukang urut perempuan yang berprofesi juga sebagai tukang balulur dapat dipanggil ke rumah-rumah (Nurdiyana dan Najamudin, 2019).

Perawatan kecantikan yang dilakukan oleh perempuan Banjar sampai sekarang masih bersifat tradisional. Dari bahan yang diramu, teknik pengolahan, dan proses perawatan kecantikan masih menggunakan bahan-bahan dan perlengkapan alami dan tradisional. Rumah cantik yang ada di Kota Banjarmasin pada umumnya mengolah bahan sendiri yang masih segar dan bahkan ada yang memproduksi sendiri bahan untuk perawatan kecantikan.

Pupur dingin atau bedak dingin merupakan salah satu warisan sejarah masyarakat banjar yang turun menurun hingga sampai sekarang seperti yang dikemukakan oleh Anis (2015) menjelaskan bahwa begitu banyak definisi sejarah, secara subtansi sejarah merupakan sebuah ilmu tentang aktivitas manusia dalam rentang waktu. Dalam konteks ini diartikan, bahwa sejarah umat manusia selalu mengalami dinamika dan perubahan yang terus menerus, sehingga Allah memberhentikan waktu, maka sejarahpun akan berhenti. Seiring dengan perkembangan zaman yang ditandai dengan pesatnya perkembangan teknologi dan infomasi ditambah dengan pandangan yang merasuki sikap masyarakat, tentang hidup adalah masa kini dan masa akan datang yang mengabaikan masa lalu, sehingga memunculkan nilai-nilai baru yang berpengaruh besar terhadap tatalaku hidup bangsa Indonesia. Akan tetapi, apabila masyrakat lokalnya tetap menjaga dan melestarikan kebudayaan tersebut maka kebudayaan tersebut akan tetap ada dan bahkan akan menjadi lebih berkembang dari pada yang sebelumnya. Seperti misalnya kebiasaan masyarakat banjar yang masih menggunakan pupur dingin sebagai pelindung dari sinar matahari bahkan Pada masyarakat samarinda Pupur basah merupakan bedak yang biasanya digunakan untuk mempercantik diri dan diletakan di atas nyiru agar menjadi rebutan, kemudian dipakaikan kepada anak gadis mereka agar cepat bertemu dengan jodohnya dan menikah. 
Dikutip dari Wanulu (2016) Pada Hari kelima Proses upacara adat cumpe dan sampua suku buton di Samarinda para gadis atau kalambe buton berkumpul untuk melakukan proses pengurungan atau biasa disebut dengan pinggitan, hal pertama yang dilakukan para gadis buton dikumpulkan untuk dimandikan secara masal setelah itu gadis buton akan dikurung selama 3 hari 2 malam selama masa penggurungan gadis buton akan dilumuri pupur dingin yang dicampur dengan kunyit, pemberian pupur pertama ini biasanya akan dilakukan oleh ibu-ibu buton dari para suami dewan adat untuk memberikan sebuah doa dan kunyit pertama setelah itu para gadis buton melumuri tubuhnya masing-masing dengan kunyit dan pupur tujuan para gadis tersebut dilumuri pupur dan kunyitagar ketika keluar dari masa kurungan wanita tersebut akan terlihat lebih cantik, sedangakan untuk para peserta cumpe akan dikumpulkan dalam satu ruangan bersama anak-anak para cumpe tetapi bukan ruangan tertutup seperti sampua bersama anak dari para peserta cumpe biasanya para ibu-ibu melumuri pupurnya sendiri tanpa harus diberi oleh ibu-ibu adat dan anaknya pun harus diberikan pupur walau hanya 1 garis.

Nur (2020) dalam ritual baiyas ada aktifitas bacacantung belarap adalah paiyasan dan perempuan-perempuan tua menghias pengantin perempuan, dengan mencukur rambut-rambut halus di sekitar dahi,peilipis, kening, dan kuduk. Sedangkan becacantung adalah membentuk bulu alis mata pengantin perempuan dengan cara mencukur bulu alis kemudian dibentuk dengan pensil alis. Kemudian pengantin tadi dipupuri (dimasker) dengan pupur dingin (bedak dingin yang terbuat dari beras). Ketika ritual baiyas dilakukan bidan kampung atau paiyasan meniup-niupkan ke wajah pengantin surah Yusuf adakalanya diiringi dengan mantra-mantra berbahasa Banjar yang diakhiri dengan lapal: La ila ha illallah Muhamadurasulullah.

Ada juga salah satu Tradisi jujuran perkawinan suku tidung Tarakan Kalimantan Utara ada salah satu tahapan yaitu bepupur. bepupur sendiri dilakukan di malam hari. Acara ini dilaksanakan di rumah masing-masing akan tetapi jika salah satu dari pihak mempelai berbeda kampung maka akan dilaksanakan secara bersama-sama. Acara bepupur yaitu diamana mempelai wanita dan mempelai pria di berikan pupur dingin yang dibuat oleh masing-masing keluarga yang nantinya akan saling bertukar antar kedua keluarga mempelai. Dalam prosesi acara bepupur akan diiringi dengan kesenian hadra yang kemudian dilanjutkan dengan acara selanggo yaitu acara ini masing mempelai di pakaikan pewarnah kuku yang berwarnah merah yang berasal dari daun-daunan (Aspandi, 2016).

Ada juga Mantra yang membuat tentang bapupur dalam kebudayaan banjar yang asli berbahasa Banjar dapat dikatakan berasal dari sebelum kedatangan Islam, tetapi setelah kedatangan Islam mantra tersebut bercampur dengan ajaran-ajaran Islam, sebagai contoh bisa dilihat dari bacaan guna-guna yang satu berbahasa Banjar murni sedangkan yang lain sudah bercampur dengan ajaran Islam yang biasanya diambil dari shalawat-shalawat, doa-doa, dan juga al-Qur'an. Berikut contoh mantra yang berbahasa banjar murni: Pur sinupur Kaladi lampuyungan Lamun anakku sudah bapupur Banyak lalakian nang karindangan Mantra diatas kemudian terkena pengaruh Islam, seperti berikut: Bismillahirrahmanirrahim Pur sinupur Kaladi lampuyungan Lamun anakku sudah bapupur Banyak lalakian nang karindangan Barkat laailaahaillaah muhammaddarusulullah (Alfianoor, 2017). 


\section{KESIMPULAN}

Kecantikan tidak lepas dari etnisitas, karena suatu etnis atau masyarakat tertentu memaknai kecantikan akan berbeda dengan etnis atau masyarakat lainnya. Pada kajian ini akan membahas mengenai kecantikan dalam konteks etnisitas yaitu etnis atau masyarakat Banjar di Kota Banjarmasin Kalimantan Selatan. Perawatan kecantikan yang dilakukan oleh perempuan Banjar sampai sekarang masih bersifat tradisional. Dari bahan yang diramu, teknik pengolahan, dan proses perawatan kecantikan masih menggunakan bahan-bahan dan perlengkapan alami dan tradisional. Rumah cantik yang ada di Kota Banjarmasin pada umumnya mengolah bahan sendiri yang masih segar dan bahkan ada yang memproduksi sendiri bahan untuk perawatan kecantikan. Pupur dingin merupakan bedak tradisional Banjar khas Kalimantan Selatan. Fungsinya untuk menghaluskan, mengencangkan dan memutihkan kulit. Bedak ini sejak ratusan tahun silam memang sudah dikenal dan akrab dengan kehidupan sehari-hari orang Banjar. Pemakainya bisa laki-laki juga perempuan dan untuk segala usia. Mereka biasa memakainya di waktu senggang. Fungsi bedak dingin adalah untuk melindungi kulit dari sengatan matahari, mencegah timbulnya biang keringat, mencegah timbulnya keriput pada kulit dan menciutkan pori-pori kulit yang melebar. Pada masyarakat samarinda Pupur basah merupakan bedak yang biasanya digunakan untuk mempercantik diri dan diletakan di atas nyiru agar menjadi rebutan, kemudian dipakaikan kepada anak gadis mereka agar cepat bertemu dengan jodohnya dan menikah. 


\section{REFERENSI}

Alfianoor, A. (2017). Ayat Al-Qur'an dalam Mantra Banjar. NALAR: Jurnal Peradaban dan Pemikiran Islam, 1(1), 27-47.

Anis, M. Z. A. (2013). ILMU SEJARAH SEBAGAI SUMBER PEMBELAJARAN IPS. Mewacanakan Pendidikan IPS, 149.

Anis, M. Z. A. (2015). Sejarah Bukan Warisan Melainkan Pembelajaran.

Anis, M. Z. A., \& Mardiani, H. S. S. F. (2021). Analysis of the Effectiveness of MPBH: The Mains of Mandai as a Saving Food in Banjarmasin Community.

Arisanty, D., Normelani, E., Putro, H. P. N., \& Anis, M. Z. A. (2019). The role of local government for local product processing: the implication for tourism sustainability in Lok Baintan Floating Market. Journal of Indonesian Tourism and Development Studies, 7(1), 7-12.

Arisanty, D., Putro, H. P. N., Normelani, E., \& Anis, M. Z. A. (2020). Women Traders Livelihoods in Tourism Area of Lok Baintan Floating Market. Journal of Indonesian Tourism and Development Studies, 8(1), 25-32.

Aspandi, A. (2016). TRADISI JUJURAN PERKAWINAN SUKU TIDUNG TARAKAN KALIMANTAN UTARA DALAM PERSPEKTIF MASLAHAT. Al-'Adalah: Jurnal Syariah dan Hukum Islam, 1(3), 16-49.

Banjar, K. P. K. (2019). Penerapan Teknologi Tepat Guna Dalam Upaya Peningkatan Produksi Pengrajin Bedak Dingin di.

Dewi Muliyawan, dkk. 2013. A - Z Tentang Kosmetik. Jakarta: PT Elex Media Komputindo.

Dianzy, R. I. K. (2015). Pengaruh Proporsi Pati Bengkuang dan Tepung kacang Hijau Terhadap Sifat Fisik Dan Jumlah Mikroba Bedak Dingin. Jurnal Tata Rias, 4(01).

Nur, N., \& Jailani, M. S. (2020). TRADISI RITUAL BEPAPAI SUKU BANJAR: MANDI TOLAK BALA CALON PENGANTIN SUKU BANJAR KUALA-TUNGKAL PROVINSI JAMBI, INDONESIA. Khazanah: Jurnal Studi Islam dan Humaniora, 18(2), 287-308.

Nurdiyana, T., \& Najamudin, M. (2019). Konstruksi Sosial Budaya kecantikan Perempuan Banjar dalam Bingkai Budaya Banjar pada Masyarakat Banjar di Kota Banjarmasin.

Rafiek, M., \& Anis, M. Zainal Arifin. 2004. Eksistensi Wiramartas dalam Hikayat Banjar. Wiramartas. Jurnal Sosial dan Pendidikan, 1(1), 1-10.

Wanulu, R. (2016). Makna Interaksi Simbolik Pada Proses Upacara adat Cumpe Dan Sampua Suku Buton Di Samarinda. Jurnal IImu Komunikasi, 4(3), 265-279. 